\title{
A functional food: a traditional Tarhana fermentation
}

\author{
Merih KIVANÇ^, Ebru Güney FUNDA²
}

\begin{abstract}
White wheat flour, concentrated full fat yoghurt, tomato paste, onion, red and green paprika, and mint and salt are used in the preparation of Tarhana. During the 7-day Tarhana fermentation period, the acidity increased from $1.10 \%$ to $3.25 \%$, the $\mathrm{pH}$ decreased from 5.22 to 4.13 , and the moisture decreased from $70.12 \%$ to $26.15 \%$. The chemical composition of the Tarhana at the end of fermentation was determined as: moisture $9.55 \%$, protein $12.05 \%$, total ash $5.65 \%$, salt $5.65 \%$, and fat $4.88 \%$. During the fermentation, the lactic acid bacteria count of increased from $1.32{\mathrm{X} 10^{2}}^{2}$ to $4.20 \mathrm{X} 10^{4} \mathrm{CFU} / \mathrm{g}$, the total mesophilic aerobe

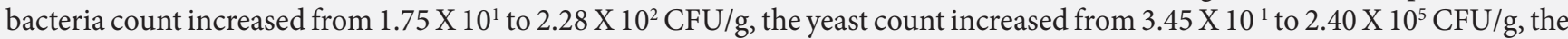
mould count from $1.55 \times 10^{1}$ to $2.45 \times 10^{4} \mathrm{CFU} / \mathrm{g}$, in the content of Tarhana dough. It was observed that Lactococcus lactis spp. lactis, Leuconostoc mesenteroides, Lactobacillus acidophilus, Enterococcus durans, Pediococcus spp., Lactobacillus delbrueckii ssp. lactis and Lactobacillus paracasei bacteria played a role during the fermentation of Tarhana dough. Kluyveromyces marxianus, Yarrowia lipolytica, Pichia membranaefaciens, Pichia mexicana, Pichia angusta, Debaryomyces hansenii, Candida sorboxylosa, Candida fluviatilis, Saccharomyces cerevisiae were identified during the Tarhana fermentation.
\end{abstract}

Keywords: Tarhana; lactic acid bacteria; yeast; fermentation.

Practical Application: Tarhana is going to be a healthy food.

\section{Introduction}

Tarhana is a traditional Turkish food, which is a fermented cereal food produced at homes and also in commercially. It has a high nutritive value. Tarhana is a source of vitamin, protein and minerals (Dağlığlu, 2000; Özdemir et al., 2007). Different preparation techniques are used to make the Tarhana. Turkish fermented Tarhana is made with cereal flour, yoghurt, vegetables, spices. Four different types of Tarhana defined by the Turkish Standardization Institute (Turkish Standards Institution, 1981). Such as when broken wheat is used instead of wheat flour, this is called Göce Tarhana. Dough of the Tarhana is prepared after 1-7 days lactic and alcoholic fermentation. Then dough is sun dried and ground. Traditionally grounded dough of the Tarhana is used to make soup. It has sour taste and acidic with a yeastly flavour. There are several products similar to Tarhana in different countries. They are known as Thanu in Hungary, Trahanas in Greece, Talkuna in Finland, Kishk in Syria, Palestine, Jordan, Lebanon and Egypt, Kushuk in Iraq and Iran (Siyamoğlu, 1961; Blandino et al., 2003).

The characteristic taste and flavour of the Tarhana is given lactic acids, ethanol, carbon dioxide, and some organic compounds produced by LAB and yeast (Dağlioğlu, 2000). The Tarhana fermentation causes, to a limited extent, some protein break-downs due to the proteolytic activity of the lactic acid bacteria, and yeast (Ibanoğlu et al., 1995). Because of its own moisture content and low $\mathrm{pH}$, Tarhana can be stored for 2 to 3 years (Salama et al., 1992).
There are studies that about the influence of the different production techniques on Tarhana characteristics (Siyamoğlu, 1961; Ibanoğlu et al., 1995; Dağlioğlu, 2000; Erbaş et al., 2004, 2005; Ekinci, 2005; Erkan et al., 2006), but a limited number of microbiological studies were performed. These studies include the determination of the number of aerobic bacteria, coliforms, mould and yeast (Erbaş et al., 2005; Siyamoğlu, 1961). However, there has been one study conducted about the studies of the identification of yeast and lactic acid bacteria (LAB) isolation to date (Sengun et al., 2009). Therefore, the purpose of this study was to identify the LAB and yeast obtained from Tarhana dough during fermentation and chemical changes in Tarhana dough during fermentation have been carried out.

\section{Materials and methods}

\subsection{Materials}

White wheat flour, full fat yoghurt, red and green pepper, tomato paste, onion, mint and salt that were used in Tarhana preparation, were bought from local markets in Eskişehir Turkey.

\subsection{Tarhana production}

The Tarhana were prepared according to Özdemir et al. (2007). To prepare the Tarhana in laboratory conditions, $1000 \mathrm{~g}$ flour, $700 \mathrm{~g}$ yoghurt, $85 \mathrm{~g}$ tomato paste, $78 \mathrm{~g}$ chopped onions, $35 \mathrm{~g}$ red pepper, $17 \mathrm{~g}$ green pepper, $12 \mathrm{~g}$ salt, and $4.5 \mathrm{~g}$ mint were mixed and kneaded. After combining and mixing the ingredients, the 
dough was incubated at $35^{\circ} \mathrm{C}$ for $7 \mathrm{~d}$ in a glass jar, and dried in an air convection oven at $55^{\circ} \mathrm{C}$ for $72 \mathrm{~h}$. The dried samples were ground and stored in glass jars at room temperature until used (Figure 1). All the experiments were replicated twice.

\subsection{Enumeration of the microorganism}

Ten grams tarhana sample was weighed aseptically and homogenized by adding physiological saline solution $(90 \mathrm{ml})$. The total number of the mesophilic aerobic bacteria (TMAB) was counted on the plate count agar (PCA, Oxoid CM463, Basingstoke, UK) and incubated for 48 hour at $30{ }^{\circ} \mathrm{C}$ (Turkish Standards Institution, 1981).

The dichloran rose bengal chloramphenicol agar (DRBCA, Oxoid CM727, Basingstoke, UK) and potato dextrose agar (PDA, Merck) were used to determine the total number of yeasts and moulds, and incubated at $25^{\circ} \mathrm{C}$ for $4-5$ days. Dea'k and Beuchat modified the simplified identification method (SIM) (Dea'k \& Beuchat, 1996). The SİM methods includes, the morphological examination, urea hydrolysis, the growth in cycloheximide, and the fermentation of glucose. The selected yeast isolate was transferred onto a BUY medium. Suspension was inoculated on YT Biolog

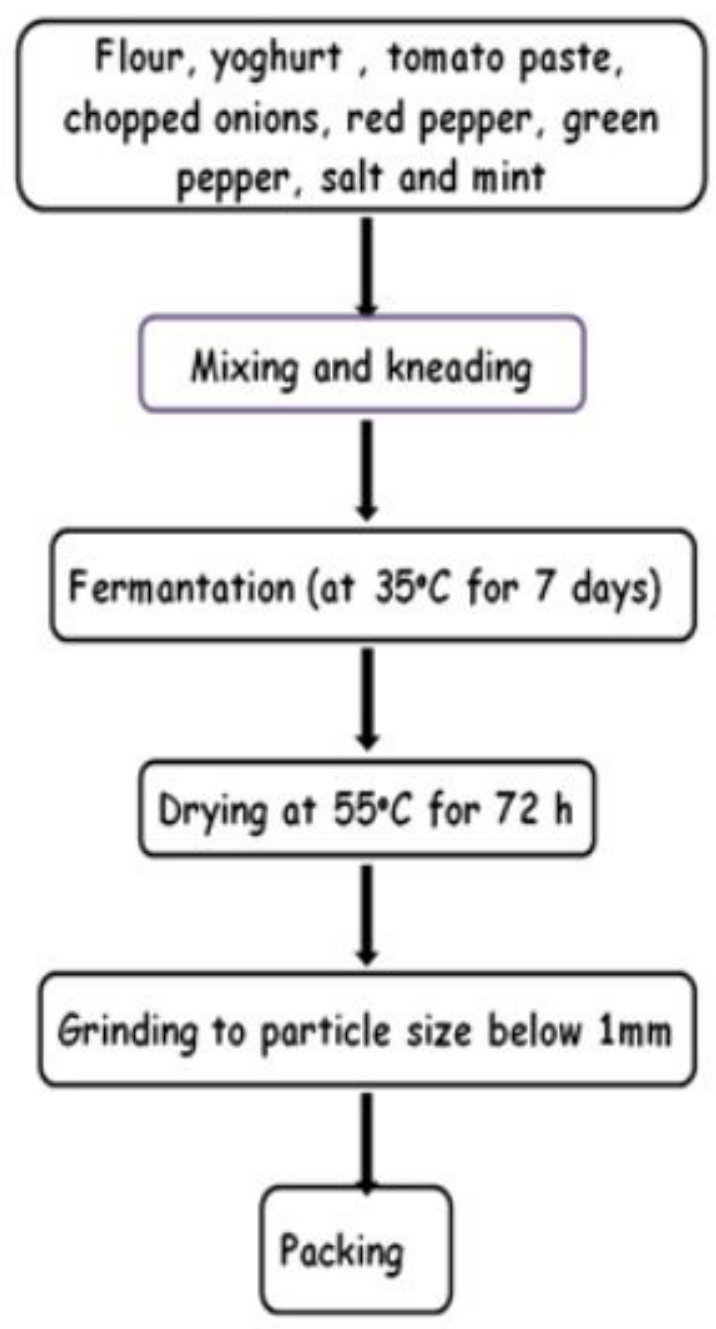

Figure 1. The schematic diagram of tarhana production. plates according to the manufacturer's recommendations. Plates were incubated for 24 to 48 hours at $30^{\circ} \mathrm{C}$ Biolog_software (Biolog, 2001) was used for identification results. Well identified strains match with a known species with high probability $(95 \%$ or higher). Under $95 \%$ probable matches were analysed with the API ID32C system (bioMe' rieux) according to manufacturer guides. Dalmau procedure that was described by Kreger van rij in 1984 was used for analysing vegetative reproduction and the formation of the mycelia or pseudomycelia (Kreger van rij 1984). The formation of the ascospores was examined according to Van der Walt \& Yarrow (1984) and Barnett et al. (2000) in sporulating media.

The lactic acid bacteria were evaluated de Man, Rogosa and Sharpe agar (MRS), and M17 agar (Merck). The plates were incubated anaerobically at $30^{\circ} \mathrm{C}$ for 5 days (Harrigan \& McCance, 1976). All the plates were studied for typical colony types and morphological characteristics (U.S. Food \& Drug Administration, 1998). Gram-positive, catalase-negative isolates were accepted as most likely LAB. Isolates were identified according to Schillinger \& Lucke (1987). API 50 CHL kit was used for Carbohydrate fermentation tests according to the manufacturer guideline (BioMerieux, France). Automatic RiboPrinter ${ }^{\circledR}$ Microbial Characterization System (Dupont Qualicon) and the standard EcoRI DNA preparation kit were used for Ribotyping.

The Coliforms and Escherichia coli were enumerated on Violet Red Bile Agar (VRBA, Oxoid CM485, Basingstoke, UK). Plates were incubated for 48 hours at $37^{\circ} \mathrm{C}$. The colonies in the pink to red colour were isolated. These isolates re-cultured on Eosin Methylene Blue Agar (EMB, Oxoid CM69, Basingstoke, $\mathrm{UK})$, then incubated at $48 \mathrm{~h}$ for $37^{\circ} \mathrm{C}$. IMVIC tests were done on the greenish metallic colonies to identify the E. coli.

\subsection{Chemical analysis}

Five grams tarhana sample was homogenized in $45 \mathrm{~mL}$ distilled water. The $\mathrm{pH}$ of the samples was determined by $\mathrm{pH}$ meter (Turkish Standards Institution, 1981).

The moisture level of the Tarhana dough and dried Tarhana samples $(0.5 \mathrm{~g})$ was measured by drying the samples at $105 \pm 5^{\circ} \mathrm{C}$ for 1 hour in an air oven (Turkish Standards Institution, 1981).

Total acidity values of the Tarhana dough and dried Tarhana samples was determined titrimetric method (Turkish Standards Institution, 1981; Association of Official Analytical Chemists, 1990).

The ash content was determined using Tarhana standard methods (Method TS 2282) (Turkish Standards Institution, 1981).

The nitrogen content was determined by the Kjeldahl method. Results were expressed as percent protein on dry weight basis (Salama et al., 1992; Dağlioğlu, 2000; Association of Official Analytical Chemists, 1990).

The Soxhlet method was used for assessing the total ether extract (Turkish Standards Institution, 1981; Association of Official Analytical Chemists, 1990). The salt content was evaluated according to Elgun et al. (1999). 


\section{Results and discussion}

The changes in the bacteria and yeast number in the Tarhana dough during fermentation are given in Figure 2. At initial part of the fermentation, the number of yeast, moulds, TMAB, LAB, were found similar. The TMAB count increased rapidly within 3 days of fermentation. Probably reduction in the TMAB count at the time of fermentation was because of the rise in the acid content and also, the formation of substances such as, hydrogen peroxide, ethanol, diacetyl, carbon dioxide and bacteriocins or bacteriocin -like substances .

The LAB and yeast count increased within 5 days of the fermentation. Similar results were found in the previous studies (Erbaş et al., 2005).

The lactic acid bacteria and yeast were responsible for the flavour and taste of Tarhana. LAB and yeast produce lactic acid, ethanol, carbon dioxide, and some organic compounds. The organic acids produced during fermentation cause the lower $\mathrm{pH}$, and after the fermentation, the excess moisture is removed by drying, and thus, a natural aroma is created (Dağlioğlu, 2000). The characteristic taste of tarhana depends on co-working of the lactic acid bacteria and yeast. Production of volatile acids and ethanol lead to acid formation. Despite the disappearing of these compounds during drying process, they provide the desired flavour of Tarhana. The yeast and lactic acid bacteria identified during fermentation are given in Table 1. A total of 640 lactic acid bacteria and 545 yeast were isolated. From the

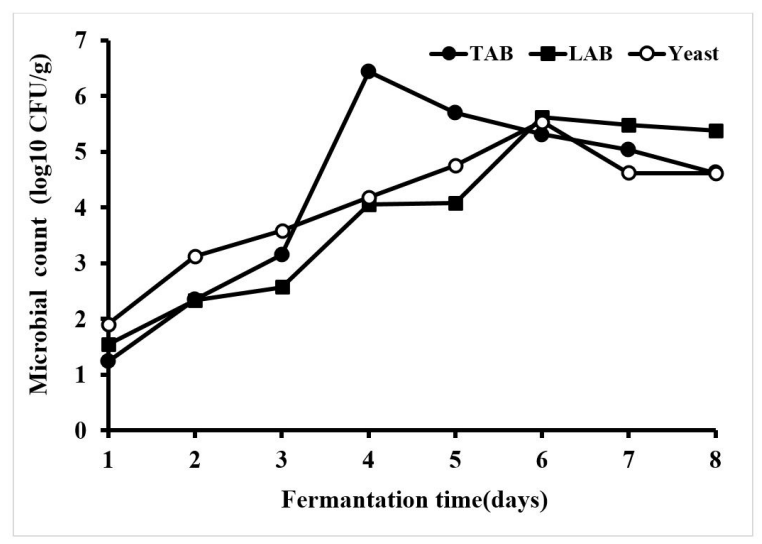

Figure 2. Effect of fermentation time on microorganisms counts of Tarhana dough.

Table 1. Yeast and lactic acid bacteria during fermentation identified.

\begin{tabular}{|c|c|c|c|c|c|c|}
\hline Fermentation days & Yeast & $\mathrm{n}$ & $\%$ & Lactic acid bacteria & $\mathrm{n}$ & $\%$ \\
\hline \multirow{3}{*}{0} & K. marxianus & 50 & 71.4 & L. lactis spp. lactis & 28 & 35.0 \\
\hline & Y.lipolytica & 20 & 28.6 & L. plantarum & 50 & 62.5 \\
\hline & & & & L. acidophilus & 2 & 2.5 \\
\hline \multirow{3}{*}{1} & Y. lipolytica & 28 & 35 & L. lactis spp. lactis & 25 & 31.3 \\
\hline & P.membranaefaciens & 7 & 8.8 & L. plantarum & 45 & 56.3 \\
\hline & K.marxianus & 45 & 56.3 & L. brevis & 10 & 12.5 \\
\hline \multirow{5}{*}{2} & P.mexicana, & 1 & 1.3 & Lactococcus lactis spp. lactis & 20 & 30.8 \\
\hline & $P$. angusta & 1 & 1.3 & Lactobacillus plantarum & 40 & 61.5 \\
\hline & Y. lipolytica & 30 & 40.0 & Lactobacillus brevis & 5 & 7.7 \\
\hline & K.marxianus & 40 & 53.3 & & & \\
\hline & D.hansenii & 3 & 4.0 & & & \\
\hline \multirow{3}{*}{3} & K.marxianus & 30 & 54.5 & Pediococcus spp. & 5 & 6.3 \\
\hline & Y. lipolytica & 22 & 40.0 & L. lactis spp. lactis & 35 & 43.8 \\
\hline & D. hansenii & 3 & 5.45 & L. plantarum & 40 & 50.0 \\
\hline \multirow{4}{*}{4} & P.membranaefaciens & 2 & 3.1 & Pediococcus spp. & 5 & 6.3 \\
\hline & D.hansenii & 2 & 3.1 & L. lactis spp. lactis & 35 & 43.8 \\
\hline & K. marxianus & 3328 & 50.8 & L. plantarum & 40 & 50.0 \\
\hline & Y. lipolytica & & 43.1 & & & \\
\hline \multirow{5}{*}{5} & C. sorboxylosa & 2 & 2.9 & L. lactis spp. lactis & 20 & 25.0 \\
\hline & C. fluviatilis & 2 & 2.9 & Pediococcus spp. & 5 & 6.3 \\
\hline & Y. lipolytica & 25 & 35.7 & E.s durans & 15 & 18.8 \\
\hline & S. cerevisiae & 10 & 14.3 & L. paracasei ssp. paracasei & 10 & 1.3 \\
\hline & K. marxianus & 31 & 44.3 & L.plantarum & 30 & 37.5 \\
\hline \multirow{5}{*}{6} & G. terrestre & 2 & 3.1 & Pediococcus spp. & 6 & 14.7 \\
\hline & Y. lipolytica & 18 & 27.7 & L. lactis spp lactis & 16 & 20.5 \\
\hline & K. marxianus & 25 & 38.5 & E. durans & 23 & 29.5 \\
\hline & S.cerevisiae & 20 & 30.8 & L. plantarum & 20 & 25.6 \\
\hline & & & & L. paracasei ssp. paracasei & 13 & 16.7 \\
\hline \multirow{7}{*}{7} & Scerevisiae & 22 & 33.9 & L.delbrueckii sp. delbrueckii & 5 & 7.3 \\
\hline & Kmarxianus & 26 & 40.0 & L.s lactis spp.lactis & 10 & 12.5 \\
\hline & Y lipolytica & 17 & 26.2 & L. mesenteroides sp. cremoris & 10 & 12.5 \\
\hline & & & & Pediococcus spp. & 6 & 7.5 \\
\hline & & & & E. durans & 23 & 28.8 \\
\hline & & & & L. paracasei ssp paracasei & 11 & 13.8 \\
\hline & & & & L. plantarum & 15 & 18.8 \\
\hline
\end{tabular}


640 lactic acid bacteria isolates, 623 were identified as lactic acid bacteria (Table 1). Lactococcus lactis spp. lactis, L. plantarum were the dominant $\mathrm{LAB}$ isolated during day 0 and 3 , while Pediococcus spp. was seen later in the fermentation. Further, for day 7 Lactobacillus delbrueckii spp. delbrueckii, Leuconostoc mesenteroides sp. cremoris were detected. Lactococcus lactis spp. lactis was isolated from all the stages of fermentation. Additionally, results of the RiboPrinter ${ }^{\circledR}$ Microbial Characterization System (Dupont Qualicon) are given in Figure 3. In a study similar to this study, Lazos et al. (1993) found the L. cremoris, S. lactis, S. diacetylactis, L. casei, L. lactis,, L. delbrueckii spp. bulgaricus and L. acidophilus are predominant LAB. LAB found in Kishk, which is similar to Tarhana were reported to be, L. brevis, L. plantarum and L. casei in previous studies (Morcos et al., 1973;

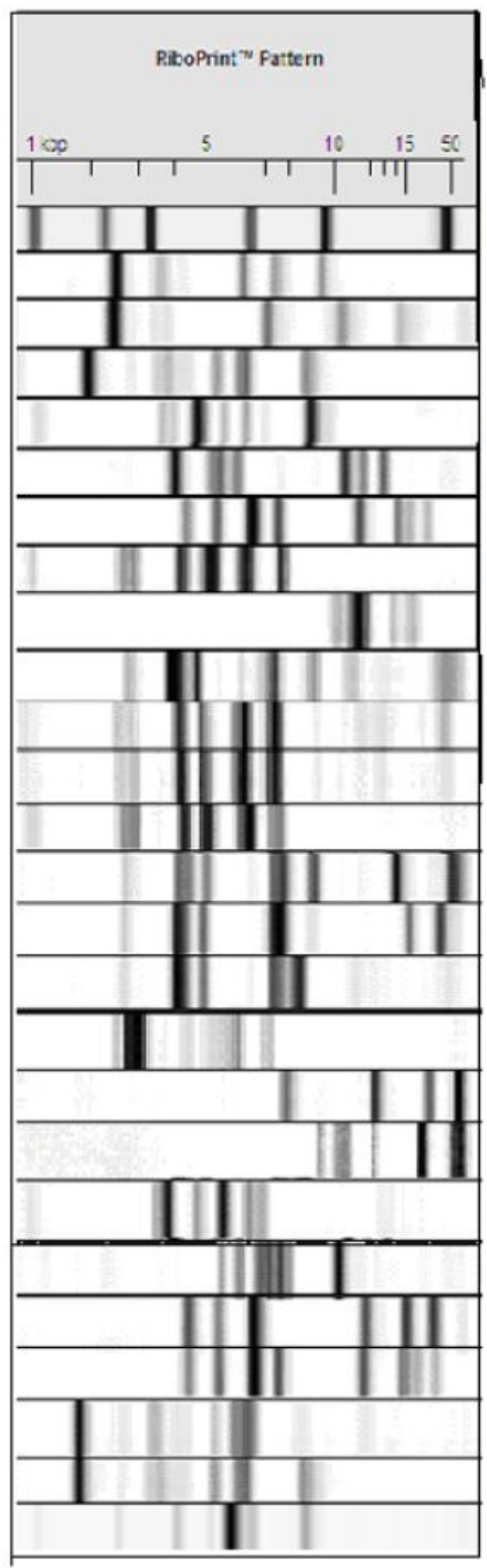

Marker

E.faecium (DUP- 16416)

E.feacalis (DUP-15215)

E. durans (DUP-6209)

P.acidilactici (DUP-13216)

L.fermentum (DUP-14412)

L. paracasei spp. paracasei (DUP-18181)

L.plantarm (DUP-16541)

Leu. citreum (DUP-13515)

L.brevis (DUP-14534)

L.plantarm

L.plantarm

L.plantarm

L.brevis

L.brevis

L.brevis

L. delbrunckii spp.delbrunckii

L.mesenteriodes

Leuconostoc spp.

Pediococcus spp.

L. Lactis spp.lactis

L. paracasei spp. paracasei

L. paracasei spp. paracasei

E. durans

E.durans

L.acidophilus

Figure 3. Ribotyping profiles of isolates and some standards shown with DUP numbers. 
Table 2. Composition and $\mathrm{pH}$ of dried Tarhana.

\begin{tabular}{ccccccc}
\hline Moisture (\%) & $\begin{array}{c}\text { Crude protein } \\
(\mathbf{g} / \mathbf{1 0 0} \mathbf{g})\end{array}$ & $\begin{array}{c}\text { Ash } \\
(\mathbf{g} / \mathbf{1 0 0 g})\end{array}$ & $\begin{array}{c}\text { Lactic acid } \\
(\mathbf{g} / \mathbf{1 0 0} \mathbf{g})\end{array}$ & $\begin{array}{c}\text { Salt } \\
(\mathbf{g} / \mathbf{1 0 0} \mathbf{g})\end{array}$ & $\begin{array}{c}\text { Ether extract } \\
(\mathbf{g} / \mathbf{1 0 0} \mathbf{g})\end{array}$ & $\begin{array}{c}\text { pH } \\
4.55\end{array}$ \\
\hline 12.05 & 5.65 & 3.30 & 5.65 & 4.88 & 4.13 \\
\hline
\end{tabular}

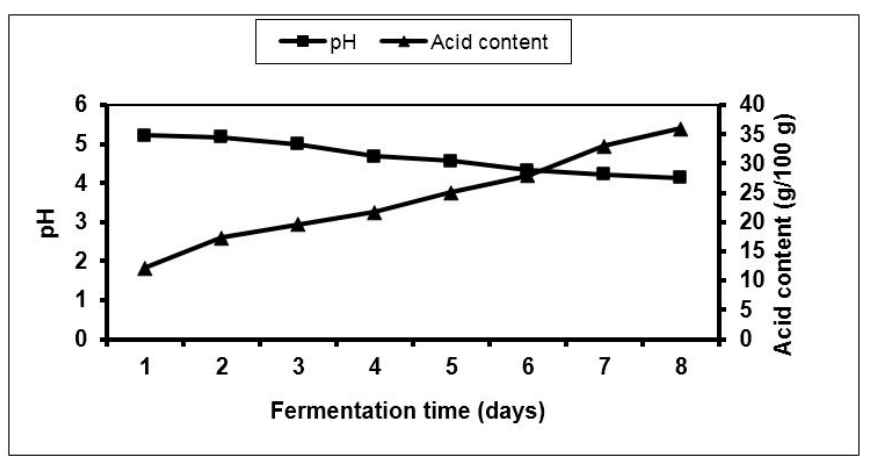

Figure 4. Change in acid content and $\mathrm{pH}$ values of Tarhana depending on fermentation.

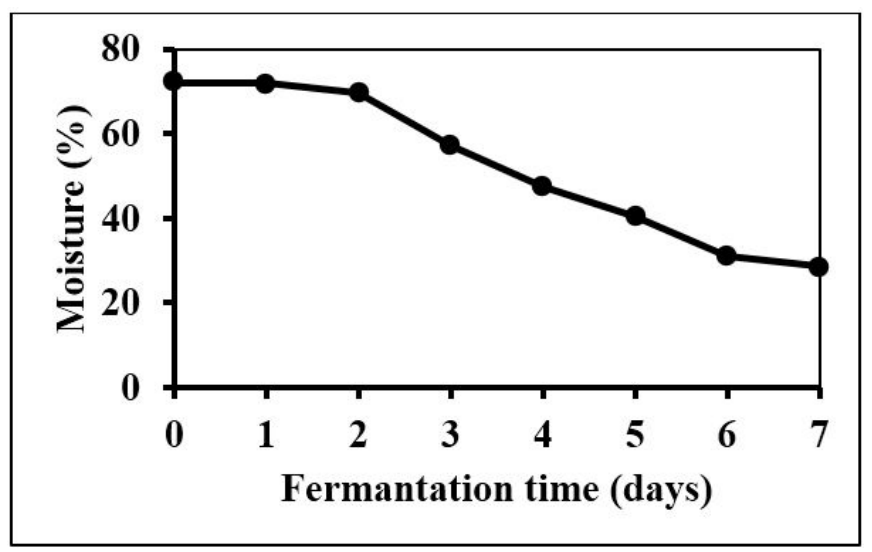

Figure 5. Change in moisture content of Tarhana depending on fermentation.

El-Gendy 1983). Sengun et al. (2009) found a P. acidilactici and S. thermophilus predominant LAB.

Kluyveromyces marxianus and Yarrowia lipolytica, Pichia membranaefaciens, Pichia mexicana, Pichia angutsa, Debaryomyces hansenii, Candida sorboxylosa, Saccharomyces cerevisiae, Candida fluviatilis, Geotrichum terrestre were identified in the Tarhana samples during the fermentation periods in our study. K. marxianus and Y. lipolytica were isolated from all the stages of the fermentation and $S$. cerevisiae, K. marxianus and Y. lipolytica dominanted the final stages of it. The addition of the yeast source into the recipe or making changes in the type and amount of yoghurt, affects the micro-flora and the development of the fermentation (Dağlioğlu, 2000). Coliforms were not found from Tarhana samples during the fermentation periods. Consequently, this result indicates that there was no contamination from the raw materials and environment. Mould growth was not observed in any samples.

Tarhana samples during the fermentation periods or in the microorganisms growth in the dried Tarhana samples. The dried
Tarhana, with a low $\mathrm{pH}$ (4.13) and low moisture content (9.55\%), is a poor medium for pathogens and spoilage organisms.

At the initiating part of the fermentation, the acid content increased, the $\mathrm{pH}$ decreased, but during the fermentation, the increase in the acid content and the decrease in $\mathrm{pH}$ slowed down (Figure 4). In this case due to the formation of organic acids with the fermentation of the carbohydrate by LAB. Similar results were found in previously studies (Lazos et al., 1993; Ibanoğlu et al., 1995). The positive relationship between lactic acid and lactic acid bacteria during kishk fermentation was shown by Damir et al. (1992).

The moisture of the dough decreased during the fermentation (Figure 5). The moisture content of the dried Tarhana was determined to be $9.55 \%$. At the end of the fermentation time, the crude protein, the ash and salt contents of the dried Tarhana were found to be $12.05,5.65$ and $5.65 \mathrm{~g} / 100 \mathrm{~g}$ respectively (Table 2). These results are similar to those reported by Dağlioğlu (2000), Erbaş et al. (2005) and Lazos et al. (1993). The pH of the final dried Tarhana was $4.07-4.75$, the acidity $0.60-1.00 \%$, the moisture content $8.6-11.5 \%$, and the protein content $10.4-13.6 \%$. The product offers possibilities as an increased nutritive value or high-protein food (Lazos et al., 1993).

\section{Conclusion}

Based on the findings that have been obtained from this study, it can be concluded that the various species of yeast and the lactic acid bacteria occurring in Tarhana during natural fermentation (LAB) were the dominating strains. E. durans, L. plantarum, S. cerevisiae, K.marxianus and Y. lipolytica dominated the final stages of the fermentation. The cereals accumulated a considerable amount of phytic acid (myo-inositol-1, 2, 3, 4, 5, 6-hexakis dihydrogen phosphate) during maturation. Bioavailability of $\mathrm{Ca}^{+2}, \mathrm{Mg}^{+2}, \mathrm{Fe}^{+2 /+3}, \mathrm{Zn}^{+2}, \mathrm{Mn}^{+2}$ are interrupted by the phytates that are found in the diet (Fredlund et al., 2006). L. plantarum produced high levels of extracellular and intracellular phytase (Sumengen et al., 2013). The production of natural, safe and healthy food where lactic acid fermentation exerts an important biopreservative effect is paramount. LAB and its metabolites act as biopreservatives in food systems. LAB can be used in cereal food products owing to its detoxification of mycotoxins and production of phytase.

\section{Acknowledgements}

This research was supported by Anadolu University Research Found, with project no. 071007.

\section{References}

Association of Official Analytical Chemists - AOAC. (1990). Officinal methods of analysis of the association of official analytical chemists (15th ed). Arlington: AOAC. 
Barnett, J. A., Payne, R. W., \& Yarrow, D. (2000). Yeasts: characteristics and identification. Cambridge: Cambridge University Press.

Biolog. (2001). Instructions for use of the biolog GP2, GN2 and YT microplates TM. Harward: Biolog, Inc.

Blandino, A., Al-Aseeri, M. E., Pandiella, S. S., Cantero, D., \& Webb, C. (2003). Cereal-based fermented foods and beverages. Food Research International, 36(6), 527-543. http://dx.doi.org/10.1016/ S0963-9969(03)00009-7.

Dağlioğlu, O. (2000). Tarhana as a traditional Turkish fermented cereal food. Its recipe, production and composition. Die Nahrung, 44(2), 85-88. PMid:10795573. http://dx.doi.org/10.1002/(SICI)15213803(20000301)44:2<85::AID-FOOD85>3.0.CO;2-H.

Damir, A. A., Salama, A. A., \& Safwat, M. (1992). Acidity, microbial, organic and free amino acids development during fermentation of skimmed milk in Kishk. Food Chemistry, 43(4), 265-269. http:// dx.doi.org/10.1016/0308-8146(92)90210-S.

Dea'k, T., \& Beuchat, L. R. (1996). Handbook of food spoilage yeasts (210 p.). Boca Raton: CRC Press.

Ekinci, R. (2005). The effect of fermentation and drying on the watersoluble vitamin content of tarhana, a traditional Turkish cereal food. Food Chemistry, 90(1-2), 127-132. http://dx.doi.org/10.1016/j. foodchem.2004.03.036.

El-Gendy, S. M. (1983). Fermented foods of Egypt and the Middle East. Journal of Food Protection, 46(4), 358-367. http://dx.doi. org/10.4315/0362-028X-46.4.358.

Elgun, A., Ertugay, Z., Certel, M., \& Kotancilar, G. (1999). Tahıl ve ürünlerinde analitik kalite kontrolü. Erzurum: Atatürk Üniversity.

Erbaş, M., Certel, M., \& Uslu, M. K. (2005). Microbiological and chemical properties of tarhana during fermentation and storage as wet-sensorial properties of tarhana soup. LWT - Food Science and Technology, 38(4), 409-416. http://dx.doi.org/10.1016/j.lwt.2004.06.009.

Erbaş, M., Uslu, K. M., Erbaş, O. M., \& Certel, M. (2004). Effects of fermentadion and storage on the organic and fatty acid contents of tarhana, a Turkish fermented cereal food. Journal of Food Composition and Analysis, 19(4), 294-301. http://dx.doi.org/10.1016/j. jfca.2004.12.002.

Erkan, H., Çelik, S., Bilgi, B., \& Köksel, H. (2006). A new approach for the utilization of barley in food products: barley tarhana. Food Chemistry, 97(1), 12-18. http://dx.doi.org/10.1016/j.foodchem.2005.03.018.

Fredlund, K., Isaksson, M., Rossander-Hulthe, L., Almgren, A., \& Sandberg, A. S. (2006). Absorption of zinc and retention of calcium: dose-dependent inhibition by phytate. Journal of Trace Elements in Medicine and Biology, 20, 49-57. http://dx.doi.org/10.1016/j. jtemb.2006.01.003.
Harrigan, W. F., \& McCance, M. E. (1976). Laboratory methods in food and dairy microbiology. London: Academic Press.

Ibanoğlu, S., Ainsworth, P., Wilson, G., \& Hayes, G. (1995). Effect of formulation on protein breakdown, in vitro digestibility, rheological properties and acceptability of tarhana, a traditional Turkish cereal food. Food Chemistry, 53, 143-147. http://dx.doi.org/10.1016/03088146(95)90779-7.

Kreger-van Rij, N. J. W. (1984). General classification of the yeasts. In N. J. W. Kreger-van Rij (Ed.), The yeasts: a taxonomic study (pp. 1-44). Amsterdam: Elsevier Science Publishers.

Lazos, E. S., Aggelousis, G., \& Bratakos, M. (1993). The fermentation of Trahanas: a milk- wheat flour combination. Plant Foods for Human Nutrition, 44(1), 45-62. PMid:8332586. http://dx.doi.org/10.1007/ BF01088482.

Morcos, S. R., Hegazi, S. M., \& El-Damhougis, T. (1973). Fermented foods in common use in Egypt.I nutritive of value kishk. Journal of the Science of Food and Agriculture, 24(10), 1153-1156. PMid:4764003. http://dx.doi.org/10.1002/jsfa.2740241002.

Özdemir, S., Göçmen, D., \& Kumral, A. (2007). A Traditonal Turkish Fermented Cereal Food: Tarhana. Food Reviews International, 23(2), 107-121. http://dx.doi.org/10.1080/87559120701224923.

Salama, A. A., Damir, A. A., \& Mohamed, M. S. (1992). Effect of cooking on nutrients, microbial and sensory properties of skimmed milk and rayeb kishk. Acta Alimentalogica, 21, 67-76.

Schillinger, U., \& Lucke, F. K. (1987). Identification of lactobacilli from meat and meat products. Food Microbiology, 4(3), 199-208. http:// dx.doi.org/10.1016/0740-0020(87)90002-5.

Sengun, I. Y., Nielsen, D. S., Karapinar, M., \& Jakobsen, M. (2009). Identification of lactic acid bacteria isolated from Tarhana, a traditional Turkish fermented food. International Journal of Food Microbiology, 135(2), 105-111. http://dx.doi.org/10.1016/j.ijfoodmicro.2009.07.033.

Siyamoğlu, B. (1961). Türk Tarhanalarının yapılışı ve terkibi üzerinde bir araştırma (No. 44). Izmir: Ege Üniversitesi Ziraat Fakültesi.

Sumengen, M., Dincer, S., Kaya, A. (2013). Production and characterization of phytase from lactobacillus plantarum. Food Biotechnology, 27, 105-118. http://dx.doi.org/10.1080/08905436.2013.781507.

Turkish Standards Institution - TSE. (1981). TSE - TS 2282: official methods of analysis. Ankara: Turkish Standards Institution.

U.S. Food \& Drug Administration - FDA. (1998). Bacteriological Analytical Manual BAM (8th ed.). Gaithersburgh: FDA.

Van der Walt, J. P., \& Yarrow, D. (1984). Methods for the isolation, maintenance, classification and identification of yeasts. In N. J. W. Kreger-van Rij (Ed.), The yeasts: a taxonomic study (pp. 45-104). Amsterdam: Elsevier Science Publishers. http://dx.doi.org/10.1016/ B978-0-444-80421-1.50009-7. 